\title{
PENGGUNAAN METODE TRANSPORTASI DALAM PROGRAM LINIER UNTUK PENDISTRIBUSIAN BARANG
}

\author{
Oleh \\ Ni Ketut Kertiasih \\ Jurusan Manajemen Informatika, FTK, Undiksha
}

\begin{abstract}
Abstrak
Permasalahan transportasi umumnya berhubungan dengan distribusi barang dan jasa dari berbagai sentra produksi ke beberapa lokasi penjualan. Pendistribusian memegang peran yang penting karena tanpa adanya pola distribusi yang tepat, maka proses ini juga dapat memakan biaya tinggi dan mengakibatkan pemborosan dari segi waktu, jarak dan tenaga. Distribusi berkaitan erat dengan kegiatan transportasi yang memadai. Salah satu solusi program linier dalam pendistribusian barang adalah dengan menggunakan metode transportasi, supaya pendistribusian barang berjalan seefektif mungkin dengan pengalokasian biaya yang minimum.
\end{abstract}

Kata kunci: metode transportasi, program linier, distribusi barang

\begin{abstract}
Transportation problems are generally related to the distribution of goods and services from various centers of production to multiple locations of sales. The distribution of an important role because without the proper distribution pattern, then this process can also take high costs and lead to waste in terms of time, distance and energy. Distribution is closely related to adequate transportation activities. One solution to the linear program in the distribution of goods is by using the method of transportation, so that the distribution of goods run as effectively as possible with the minimum cost allocation.
\end{abstract}

Key words: transportation method, linear programming, distribution of goods

\section{Pendahuluan}

Mata Kuliah Program Linier merupakan mata kuliah dasar untuk mengembangkan kompetensi ahli madya di bidang informatika. 
Berdasarkan analisis instruksional, mata kuliah ini memberikan kompetensi tentang konsep, prinsip dan yang akan menjadi dasar bagi pengembangan dan penerapan pada mata kuliah-mata kuliah selanjutnya. Berdasarkan kurikulum jurusan D3 Manajemen Informatika, mata kuliah Program Linier (3 sks) ditempatkan pada semester tiga, dimana silabus salah satu materi yang diberikan dari mata kuliah Program Linier yaitu transportasi.

Metode transportasi digunakan untuk mengatur distribusi dari sumber yang menyediakan produk yang sama ke tempattempat yang membutuhkan secara optimal. Ada beberapa metode untuk mencari solusi layak dasar awal. Tiga dari metode yang dikenal, yaitu North West Corner, Least Cost, dan Aproksimasi Vogel dan untuk mengecek optimal ada dua yaitu Metode Stepping Stone dan MODI (modified distribution). Alokasi produk ini harus diatur sedemikian rupa, karena terdapat perbedaan biaya-biaya dari satu sumber ke suatu tempat tujuan yang berbeda-beda.

Persedian atau penawaran (supplay) maksimum pada setiap sumber dan permintaan (demand) minimum pada setiap tujuan. Distribusi ini dilakukan sedemikian rupa sehingga permintaan dari beberapa tempat tujuan dapat dipenuhi dari beberapa sumber, yang masing-masing dapat memiliki permintaan atau kapasitas yang berbeda. Alokasi ini dilakukan dengan mempertimbangkan biaya pengangkutan yang bervariasi karena jarak dan kondisi antar lokasi yang berbeda. Dengan menggunakan metode transportasi, dapat diperoleh suatu alokasi distribusi barang yang dapat meminimalkan total biaya transportasi (Susanta, 1994).

Kasus transportasi timbul ketika seseorang mencoba menentukan cara pengiriman (distribusi) suatu jenis barang (item) dari beberapa sumber (lokasi penawaran) ke beberapa tujuan (lokasi permintaan) yang dapat meminimumkan biaya. Sasaran dalam persoalan transportasi ini adalah mengalokasikan barang yang ada pada sumber sedemikian rupa hingga terpenuhi semua kebutuhan pada tujuan (lokasi permintaan).

JPTK, UNDIKSHA, Vol. 6, No. 2, Juli 2009 : 27 - 35 
Adapun tujuan dari penggunanaan metode transportasi sebagai upaya untuk pendistribusian barang adalah agar supply dari beberapa sumber dapat dilakukan secara efektif dan biaya murah ke beberapa tempat tujuan. Sehubungan dengan hal tersebut, permasalahan yang akan dikaji selanjutnya adalah penggunaan metode transportasi yang dalam kajian ini membahas metode North West Corner sebagai salah satu teknik solusi dalam metode transportasi sebagai upaya untuk pendistribusian barang.

\section{Pembahasan}

\section{Program Linier}

Program Linier adalah suatu cara untuk menyelesaikan permasalahan mengenai pengalokasian/penempatan sumber-sumber yang terbatas diantara beberapa aktivitas yang bersaing, dengan cara yang terbaik yang mungkin dilakukan agar memperoleh suatu solusi yang optimal. Dalam membangun model dari formulasi permasalahan perlu digunakan beberapa pengertian sebagai berikut. (Hendi Nirwansah \& Widowati, 2007)

1. Variabel keputusan

Variabel keputusan adalah variabel yang menguraikan secara lengkap keputusan-keputusan yang akan dibuat.

2. Fungsi tujuan (objektif)

Fungsi tujuan merupakan suatu nilai sasaran yang akan diminimumkan atau dimaksimumkan. Fungsi disini merupakan bentuk hubungan antara variabel keputusan. Misalnya, memaksimalkan keuntungan, meminimalkan biaya, dan lain sebagainya.

3. Pembatas

Pembatas merupakan kendala yang dihadapi sehingga tidak bisa menentukan nilai-nilai dari variabel keputusan secara sembarang. 


\section{Persoalan Transportasi Dalam Program Linier}

Selain persoalan program linier seperti masalah optimaslisasi, metode grafik, metode simplex dan dualitas, ada persoalan program linier yang bertipe khusus, yang kekhususannya terletak pada karakteristik utama. Tipe khusus persoalan program linier yang paling penting ialah apa yang dikenal sebagai persoalan transportasi. Masalah transportasi secara umum berhubungan dengan masalah pendistribusian suatu komoditas atau produk dari sejumlah sumber (supply) ke sejumlah tujuan (demand, destination) dengan tujuan meminimumkan ongkos pengangkutan yang terjadi (biaya distribusi).

Ciri-ciri khusus persoalan transportasi adalah:

1. Terdapat sejumlah sumber dan sejumlah tujuan tertentu.

2. Kuantitas komoditas atau barang yang didistribusikan dari setiap sumber dan yang diminta oleh setiap tujuan, besarnya tertentu.

3. Komoditas yang dikirim atau diangkut dari suatu sumber ke suatu tujuan, besarnya sesuai dengan permintaan dan atau kapasitas sumber.

4. Ongkos pengangkutan komoditas dari suatu sumber ke suatu tujuan, besarnya tertentu.

Misalnya, suatu jenis barang tertentu (minyak, pupuk, telur, beras, semen, bahan bangunan, buku, dsb) akan diangkut dari beberapa tempat asal (origin) misalnya, depot, pabrik, pusat produksi, gudang, tempat penyimpanan, ke beberapa tempat tujuan (destination), misalnya pasar, agen, daerah penjualan, lokasi proyek dan sebagainya. Di dalam mengangkut barang tersebut telah diketahui biaya angkut (transportasion cost) per unit/satuan barang dari tempat asal ke tempat tujuan.

\section{Metode Transportasi}

Metode Transportasi merupakan suatu metode yang digunakan untuk mengatur distribusi dari sumber-sumber yang menyediakan produk yang sama ke tempat-tempat yang membutuhkan secara optimal dengan 
biaya yang termurah. Alokasi produk ini harus diatur sedemikian rupa karena terdapat perbedaan biaya-biaya alokasi dari satu sumber atau beberapa sumber ke tempat tujuan yang berbeda.

Model transportasi berkaitan dengan suatu situasi dimana suatu komoditas yang ingin di kirim dari sejumlah sources (sumber) menuju ke sejumlah destination (tujuan). Tujuan dari masalah tersebut adalah menentukan jumlah komoditas yang harus di kirim dari tiap-tiap sumber ke tiap-tiap tujuan sedemikian hingga biaya total pengiriman dapat di minimumkan, dan pada saat yang sama pembatas yang berupa keterbatasan pasokan dan kebutuhan permintaan tidak dilanggar. Model transportasi mengasumsikan bahwa biaya pengiriman komoditas pada rute tertentu adalah proporsional dengan banyaknya unit komoditas yang di kirimkan pada rute tersebut (Setiawan dalam Nur Hamin, 2007).

Taha dalam Fitri (1996) mengemukakan bahwa model transportasi berusaha menentukan sebuah rencana transportasi sebuah barang dari sejumlah sumber ke sejumlah tujuan. Data dalam model ini mencakup:

1. tingkat penawaran di setiap sumber dan jumlah permintaan di setiap tujuan.

2. biaya transportasi per unit barang dari setiap sumber ke setiap tujuan.

Model transportasi adalah suatu gambaran yang dituangkan ke dalam bentuk model matematika dari sebuah kasus transportasi yang dapat membantu berpikir secara cepat dan sistematik mengenai kasus tersebut. Bentuk umum dari model transportasi dapat digambarkan dalam bentuk matriks transportasi. Sebuah matriks memilki $\mathrm{n}$ baris dan $\mathrm{m}$ kolom. Pada matriks transportasi sumber-sumber terletak pada baris, sedangkan tujuan-tujuan terletak pada kolom. Notasi i digunakan untuk menandai baris ke-i, sedang notasi j digunakan untuk menandai kolom ke-j.

dimana: 
$\mathrm{Xij}$ = banyaknya unit produk atau barang yang akan dikirim dari sumber ke-i menuju tujuan ke-j

$\mathrm{Cij}=$ harga transport barang per unit dari sumber $\mathrm{i}$ ke tujuan $\mathrm{j}$

$\mathrm{Si}=$ kapasitas dari sumber ke-i

$\mathrm{Dj}$ = banyaknya permintaan barang dari tujuan ke-j

Meminimumkan $\mathrm{Z}=\sum_{\mathrm{i}=1}^{\mathrm{n}} \sum_{j=1}^{m} \mathrm{C}_{\mathrm{ij}} \mathrm{X}_{\mathrm{ij}}$ persamaan (1) dengan batasan :

(i) Keterbatasan Kapasitas Sumber ke-i :

$$
\sum_{j=1}^{n} X_{i j}=a_{i}, \text { untuk } \mathrm{i}=1,2, \ldots, \mathrm{m} \quad \ldots \ldots \ldots . \quad \text { persamaan }(2)
$$

(ii) Keterbatasan Kapasitas Tujuan ke-j :

$$
\begin{aligned}
& \sum_{i=1}^{m} X_{i j}=b_{j}, \text { untuk } \mathrm{j}=1,2, \ldots, \mathrm{n} \quad \ldots \ldots . . \quad \text { persamaan (3) } \\
& \text { dan } \mathrm{X}_{\mathrm{ij}} \geq 0 \text { untuk semua } \mathrm{i}=1,2, \ldots, \mathrm{m} \text { dan } \mathrm{j}=1,2, \ldots, \mathrm{n} .
\end{aligned}
$$

\section{Penggunaan Metode Transportasi Untuk Distribusi Barang}

Pada masalah tranportasi, biasanya jumlah barang yang disalurkan dari setiap lokasi permintaan bervariasi. Atas dasar kennyataan bahwa rute pengiriman yang berbeda akan menghasilkan biaya kirim yang berbeda, maka tujuan pemecahan kasus ini adalah menentukan berapa unit barang yang arus dikirim dari setiap sumber ke setiap tujuan sehingga permintaan dari setiap tujuan terpenuhi dan total biaya kirim minimum.

Metode North West Corner merupakan salah satu teknik solusi dalam transportasi. Metode ini didasarkan pada aturan atau pengalokasian normatif dari persediaan dan kebutuhan sumber dalam suatu matriks transportasi tanpa perhitungan besar-besaran ekonomis. Aturan normatif tersebut yaitu membebani semaksimal mungkin sampai batas maksimum persediaan atau kebutuhan (mana yang tercapai lebih dahulu) pada 
matriks alokasi pada ujung kiri atas terus menuju ke kanan bawah sedemikian hingga seluruh kebutuhan akan sumber dapat terpenuhi.

Langkah-langkahnya adalah sebagai berikut.

a. Mulai dari pojok barat laut tabel dan alokasikan sebanyak mungkin pada $X_{11}$ tanpa menyimpang dari kendala penawaran atau permintaan (artinya $X_{11}$ ditetapkan sama dengan yang terkecil diantara nilai $S_{1}$ dan $\left.D_{1}\right)$.

b. Ini akan menghabiskan penawaran pada asal barang 1 atau permintaan pada tujuan barang 1 . Sehingga, tidak ada barang lagi yang dapat dialokasikan ke kolom atau baris yang telah dihabiskan. Kemudian alokasikan sebanyak mungkin kekotak didekatnya pada baris atau kolom yang dapat dihilangkan. Jika kolom atau baris telah dihabiskan, pindahlah secara diagonal kekotak berikutnya.

c. Dengan cara yang sama proses dilanjutkan sampai semua penawaran telah dihabiskan dengan keperluan permintaan telah dipenuhi.

d. Kemudian dicari nilai biaya minimum dengan menjumlahkan seluruh alokasi yang ada dengan cara mengalikan alokasi dengan biaya transportasi.

Sebagai contoh kasus yang diselesaikan dengan menggunakan metode North West Corner yaitu ada tiga pabrik mengirim pupuk ke tiga pasar yang masing-masing pabrik berkapasitas (suplay) adalah 120,80, 80. Permintaan dari 150, 70, 60. Biaya angkut dari masing-masing pabrik 1 ketiga pelanggan adalah $8,5,6$, pabrik 2 ketiga pelanggan adalah 15 , 10,12 , dan pabrik 3 ketiga pelanggan adalah 3, 9, 10. dari permasalahan tersebut yang ingin diketahui adalah terkait dengan biaya minimum yang digunakan untuk mendistribusikan barang tersebut.

Langkah-langkah penyelesaian kasus di atas adalah:

a. Mengalokasikan nilai terkecil antara demand tujuan 1 dan supply asal 1 , nilai terkecil adalah nilai supply yaitu 120 di baris 1 dan kolom 1 diisi 120 
b. Demand pada kolom 1 belum terpenuhi, jadi dialokasikan sisa dari 150 dikurangi 120. Tujuan 1 diberikan sebanyak 30 dari pabrik 2 .

c. Karena baris 2 belum terisi penuh, maka dialokasikan sebanyak 50 sehingga baris 2 sudah terisi penuh 80 .

d. Kemudian mengalokasikan sisa dari pengurangan deman tujuan 2 dengan 50. Jadi, tujuan 2 mendapat sebanyak 20 dari asal 3

e. Selanjutnya mengalokasikan 60 ke tujuan 3 dari asal 3

f. Bentuk tabel penyelesaiannya sebagai berikut.

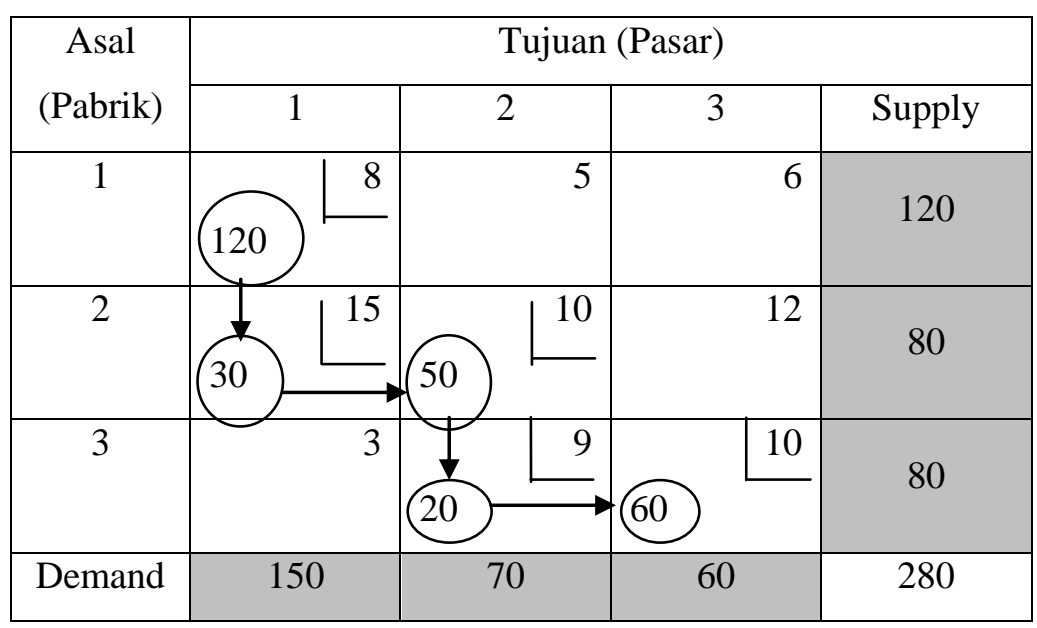

g. Langkah terakhir adalah menghitung biaya yang dikeluarkan

$$
\begin{aligned}
Z & =(8 \times 120)+(15 \times 30)+(10 \times 50)+(9 \times 20)+(10 \times 60) \\
& =960+450+500+180+600 \\
& =2690
\end{aligned}
$$

Jadi biaya yang dikeluarkan untuk distribusi barang adalah sebesar 2690.

\section{Penutup}

Distribusi berkaitan erat dengan kegiatan transportasi yang memadai. Keduanya memungkinkan berpindahnya produk dari pabrik sampai ke tujuan secara tepat waktu dan jumlah yang sesuai dan dalam 
kondisi yang baik. Diperlukan adanya penentuan urutan-urutan tujuan yang akan dikunjungi dengan armada khusus agar distribusi dapat berjalan seefektif mungkin.

Transportasi pendistribusian berbagai komoditi dari berbagai berbagai kelompok pusat penerima yang disebut tujuan sedemikian rupa sehingga meminimalisasi biaya distribusi total. Metode North West Corner dapat dijadikan sebagai salah satu solusi teknik solusi dalam transportasi sehingga pendistribusian barang dapat dilakukan seefektif mungkin dengan biaya yang minimum.

\section{Daftar Pustaka}

Fitri, Hana. (2006). "Analisis Preferensi Konsumen dan Positioning Produk Wardah di Pasar Kosmetika Jakarta". Tersedia pada http://www.iirc.ipb.ac.id/

jspui/bitstream/123456789/10308/4/H06hfi.pdf. （diakses tanggal 20 Mei 2010).

Hendri, Jhon. (2009). "Metode Transportasi". Tersedia pada http://www.hendri.staff.gunadarma.ac.id/Downloads/files/158 27/ METODE+TRANSPORTASI.pdf. (diakses tanggal 3 Juni 2010).

Nirwansah Hendi \& Widowati. (2007). "Efisiensi Biaya Distribusi Dengan Metode Transportasi" Proseding Seminar Nasional Aplikasi Sains dan Matematika Dalam Industri”. Tersedia pada

Nur Hamin, Ismaillia. (2007). "Identifikasi Alternatif Pengadaan Bahan Baku di Perusahaan Daerah Air Minum (PDAM) Kabupaten Boyolali". Tersedia pada http://www.etd.eprints.ums.ac.id/1743/2/ D600030127.pdf. (diakses tanggal 6 Juni 2010).

Susanta, B. (1994). Program Linear. Yogyakarta: Departemen Pendidikan dan Kebudayaan. 